\title{
A Profile of the Library Learning Resources Center in Small Community/Junior Colleges
}

\author{
Madison Mosley, Jr.
}

It has been suggested that nearly half of the member colleges of the American Association of Community and Junior Colleges (AACJC) consider themselves to be small or rural. However numerous, these colleges have not enjoyed the same literature coverage as their larger counterparts.

Fortunately, the plight of the small college is becoming an area of major concern. In 1976, the AACJC recognized the uniqueness of the small college and established a Task Force on Rural Community Colleges. ${ }^{1}$ This task force later developed into the Commission on Small/Rural Colleges in $1977 .^{2}$

The small two-year college, in a majority of instances, is often the higher education institution within its service area. As such, this College's mission

... extends to services that enhance the quality of life for [its] constituents. Art exhibits, plays, lectures, research and reference library services, musical and other performing group events are educational and cultural opportunities not usually available to rural communities except through a community college. ${ }^{3}$

The small comprehensive institution thus becomes a "prototype of the doeverything college, ${ }^{\prime \prime 4}$ since it attempts to meet the vocational, avocational, and college transfer needs of the diverse populations it serves.

The library learning resources centers in these colleges are often the premier libraries in the area. In addition to meeting the educational objectives of the colleges' students, these library learning resources centers assume their "responsibility to help meet the resource material need of the larger community in which [they reside] ${ }^{\prime \prime 5}$ by providing reference, circula- tion, and other services to members of the larger community.

Most published surveys of library learning resources centers have focused primarily on practices of medium- to largesized institutions. ${ }^{6}$ While such surveys are instructive, they provide little guidance to the directors of library learning resources centers in small community colleges. Because of its more limited fiscal resources, the library learning resources center in the small community college is often not able to embrace the same administrative configurations and practices that have been adopted by library learning resources centers at the larger two-year institutions.

Vineyard's comments on the rural community college aptly describe the situation of the library learning resources centers in the small community college: "There exists no disciplined research effort . . . that would describe differentially the small ... two-year institutions. . . .',7

\section{THE SURVEY}

The present descriptive study was designed to identify selected administrative practices in small, two-year, publicly supported community and junior colleges in the southeastern United States. Using the Higher Education Directory, ${ }^{8}$ this investigator compiled a list of the two-year colleges that reported enrollments of less than one thousand students. Thirty-one such institutions were identified. A questionnaire containing items related to selected aspects of the administration of library learning resources centers was developed and sent to each of the thirty-one institutions. Replies were received from twentyeight institutions. 


\section{FINDINGS}

One-half of the responding learning resources centers consisted of the functional units of the library and audiovisual services. Seven contained the library, audiovisual services, and the learning lab. Four were composed of the library, audiovisual services, and "other." Within the "other" category were public relations, GED, instructional technology, and a television studio. Two contained the library, audiovisual services, learning laboratory, and "other." These "other" included computer-assisted instruction and the print shop.

Eleven of the chief learning resources officers were called learning resources center directors. There were three who identified themselves as deans of learning resources while two were called associate deans, learning resources.

Twelve classified themselves as "other." Within this category, the librarian title occurred most frequently.

When asked to whom they reported, eighteen indicated they reported to a dean. Though the specific nature of the deanship varied, the majority of respondents reported to a dean of instruction or a dean of academic affairs. Six reported to the president of the college while two reported to "other". These "other" were also positions concerned with the instructional program.

Staffing patterns varied considerably. The number of professional staff ranged from one to four. Nine respondents reported one professional, six reported two professionals, and five had three professionals on staff (see table 1).

TABLE 1

\begin{tabular}{lc}
\multicolumn{2}{c}{ PROFESSIONAL STAFF $(\mathrm{N}=\mathbf{2 6})$} \\
\hline Number & Frequency \\
\hline 4 & 1 \\
3.5 & 1 \\
3 & 5 \\
2.5 & 1 \\
2.4 & 1 \\
2.25 & 1 \\
2 & 6 \\
1.5 & 1 \\
1 & 9 \\
\hline
\end{tabular}

Similarly, the number of support staff also varied widely. The range spread from one to 6.4. Two of the respondents reported four, and seven respondents reported three support staff members. Five respondents had only one support staff member (see table 2).

TABLE 2

SUPPORT STAFF $(\mathrm{N}=23)$

\begin{tabular}{lc}
\hline Number & Frequency \\
\hline 6.5 & 1 \\
4 & 2 \\
3 & 7 \\
2.5 & 1 \\
2 & 5 \\
1.67 & 1 \\
1.5 & 1 \\
1 & 5 \\
\hline
\end{tabular}

To the question on the organization of the collection, fifteen libraries reported using Dewey decimal classification while thirteen were using Library of Congress. Three libraries reported they were in the process of conversion. Fifteen stated their catalog was divided, and thirteen maintained a dictionary catalog. A sizable majority indicated that nonprint items were classified and cataloged, twenty-five and twenty, respectively. An overwhelming majority, twenty-seven, indicated these materials were shelved separately from the book collection.

When questioned concerning the use of their nonprofessionals, nine respondents indicated that nonprofessionals "answer reference questions that require use of reference tools." Seven indicated that their nonprofessionals also supervised other nonprofessionals. Two respondents indicated that nonprofessional staff used reference tools to answer questions and assigned classification numbers and subject headings. In addition, one respondent stated that nonprofessional staff also performed original cataloging.

Twenty-seven stated that their catalogs were in card format. Two of them indicated a conversion to COM, while two had book catalogs in off-campus locations. One library indicated that conversion to an on-line catalog was scheduled for summer 1984. Only two respondents had an on-line catalog. 
Twenty-three respondents indicated no participation in a computerized network accessible through a terminal in the learning resources center. Only three indicated that such access was available.

Twenty-six reported manual circulation systems, and two respondents indicated that some form of automated system would be installed during summer 1984 .

Twenty-two respondents reported no anti-theft system; only five had such a system.

Twenty-five respondents provided no on-line reference services. Of the two that did provide this service, each subscribed to Dialog, and both charged a fee for this service.

While seventeen of the respondents did not provide assistance to faculty in the design of instruction, eleven did provide such assistance.

\section{PROFILE}

From the data collected in this survey, the following profile of the library learning resources center in the small community and junior college emerges.

The library learning resources center consists of the library and the audio-visual components. The chief administrator is called learning resources center director and reports to the dean of academic affairs. The staff consists of two professionals and 2.4 support staff members. These support staff play a substantive role in the provision of reference service.

The collection is presently organized according to the Dewey classification system with conversion efforts under way. Audiovisual materials are classified and cataloged, but are housed separately from the book collection. The materials collection is indexed in a divided public catalog in card format. There is no commercial anti-theft system to protect the collection.

Few services are automated in the center. Circulation is handled manually, and no on-line reference services are provided. The center does not participate in networks through terminals in the library.

Technical design assistance is provided to faculty members for the development of instructional materials.

\section{CONCLUSION}

The library learning resources center in the small community and junior college shares the same objectives as its counterpart in the larger institution. However, simple "economy of size" has delayed the small center's adoption of administrative practices that are described most often in the library literature.

Small staff sizes affect both the variety and depth of services that a center can provide. In the present study, a sizable number of centers were staffed by only one professional. One person cannot possess the full array of competencies and skills needed to provide a dynamic program of services.

The lack of automated activity has some serious effects on the quality of services provided. The use of automated systems to streamline circulation brings the materials collection under better control, and staff are thus able to provide a higher level of access than is afforded by a manual system. In addition, the absence of on-line reference services denies users access to a wealth of information not locally available.

The absence of COM and on-line catalogs indicates that the centers in this study are hampered in their efforts to share their holdings beyond their immediate campuses. Since most small colleges are located in geographically remote areas, these centers cannot have records of their holdings in public libraries, or even in offcampus locations. Thus, the public's access to the college library's collections is not as extensive as it is in some urban areas.

While not addressed by this study, the issue of funding looms large in any consideration of measures for improved service. Small colleges will need to be funded differently from all other institutions.? Once these funds reach the institution, senior administrators will need to rethink the role of the library learning resources center and provide sufficient funding for an adequate staff and the necessary support facilities.

In the meantime, library learning re- 
sources center directors would do well to study the centers in small colleges and to document their needs. Qualitative standards (not guidelines) that establish minimum levels of staff, resources, and services needed for a quality program must be identified if senior administrators are to support learning resources centers as they should be supported.
Student, faculty, and community users are becoming accustomed to sophisticated services from all institutions of society. Those attending small colleges will look to the colleges and their subunits to provide efficient and effective services. The library learning resources center in the small college must meet this expectation.

\section{REFERENCES}

1. "AACJC Annual Report 1976," Community and Junior College Journal 47:31 (Feb. 1977).

2. "AACJC Annual Report 1977," Community and Junior College Journal 48:32 (Feb. 1978).

3. John M. Eaton, "A Vital Component of the Delivery System," Community and Junior College Journal 52:15 (Oct. 1981).

4. Arthur M. Cohen and Associates, College Responses to Community Demands (San Francisco: JosseyBass, 1977), p.72.

5. "Guidelines for Two-year College Learning Resources Programs (Revised): Part One," College \& Research Libraries News 43:8 (Jan. 1982).

6. See for example: Sarah Katherine Thomson, Learning Resource Centers in Community Colleges: A Survey of Budgets and Services (Chicago: American Library Assn., 1975); Lynn C. Dennison, "The Organization of Library and Media Services in Community Colleges," College \& Research Libraries 39:123-29 (Mar. 1978); and Doris Cruger Dale, "The Community College Library in the Mid1970's," College \& Research Libraries 38:404-11 (Sept. 1977).

7. Edwin E. Vineyard, "The Rural Community College," Community College Review 6:42 (Winter 1979).

8. 1984 Higher Education Directory (Washington, D.C.: Higher Education, 1984).

9. See Ali Nazari-Robati and Jacob D. Zucker, "Resolving the Financial Crisis in America's Rural Community Colleges," Community College Review 9:48-52 (Fall 1981).

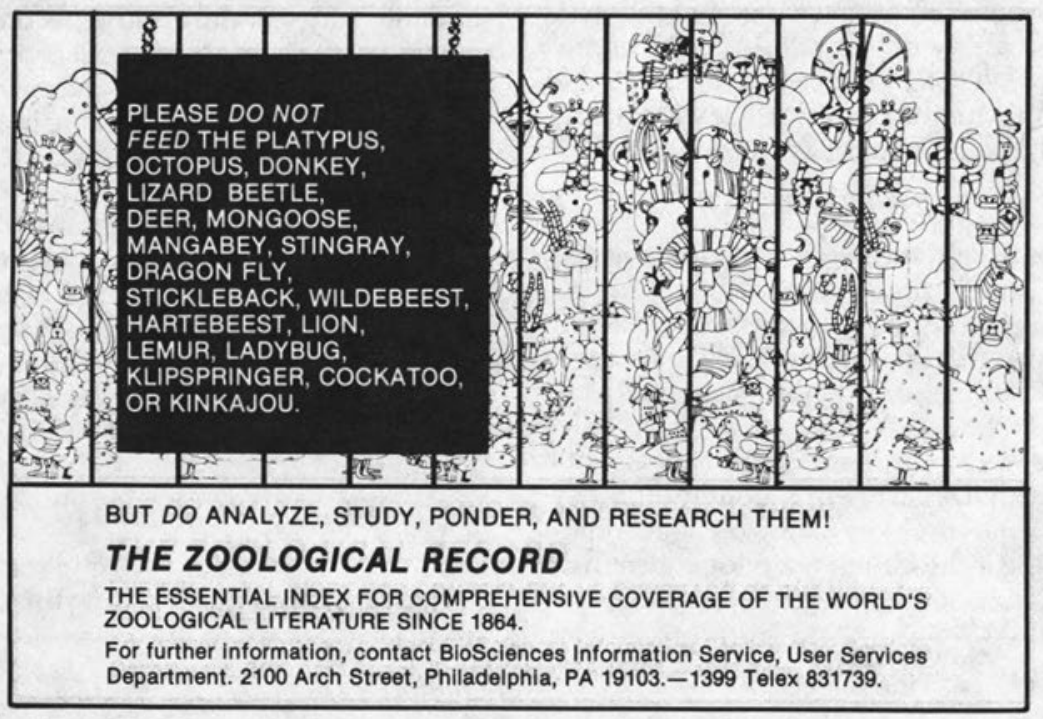

